\title{
Adaptation of Soil Solarization to the Integrated Management of Soilborne Pests of Tomato Under Humid Conditions
}

\author{
D. O. Chellemi, S. M. Olson, D. J. Mitchell, I. Secker, and R. McSorley
}

First and second authors: University of Florida, North Florida Research and Education Center, Route 3, Box 4370, Quincy 32351; third author: University of Florida, Department of Plant Pathology, Gainesville 32611; fourth author: Polyon Barkai, Kibbutz Barkai, Israel; and fifth author: University of Florida, Department of Entomology and Nematology, Gainesville 32611.

Accepted for publication 22 November 1996.

\begin{abstract}
Chellemi, D. O., Olson, S. M., Mitchell, D. J., Secker, I., and McSorley, R. 1997. Adaptation of soil solarization to the integrated management of soilborne pests of tomato under humid conditions. Phytopathology $87: 250-258$.

Soil solarization was shown to be cost effective, compatible with other pest management tactics, readily integrated into standard production systems, and a valid alternative to preplant fumigation with methyl bromide under the tested conditions. Solarization using clear, photoselective, or gas-impermeable plastic was evaluated in combination with metham sodium, 1,3-dichloropropene + chloropicrin, methyl bromide + chloropicrin, pebulate, or cabbage residue. Strip solarization, applied to $20-\mathrm{cm}-$ high, 0.9-m-wide beds, was conducted to achieve compatibility with standard production practices and resulted in soil temperatures 2 to $4^{\circ} \mathrm{C}$

white and used as a production mulch for a subsequent tomato crop. The incidence of Southern blight and the density of Paratrichodorus minor and Criconemella spp. were lower $(P<0.05)$ in solarized plots. No differences $(P<0.05)$ in the incidence of Fusarium wilt and the density of nutsedge and Helicotylenchus spp. were observed between plots receiving solarization and plots fumigated with a mixture of methyl bromide + chloropicrin. The severity of root galling was lower $(P<0.05)$ when soil solarization was combined with 1,3-dichloropropene + chloropicrin $(16.2$ $+3.4 \mathrm{~g} / \mathrm{m}^{2}$ ) and a gas-impermeable film. The incidence of bacterial wilt was not affected by soil treatments. Marketable yields in plots using various combinations of soil solarization and other tactics were similar $(P<0.05)$ to yields obtained in plots fumigated with methyl bromide + chloropicrin. The results were validated in several large scale field experiments conducted by commercial growers.
\end{abstract} above those temperatures resulting when using conventional flatbed solarization. Soil temperatures were 1 to $2^{\circ} \mathrm{C}$ higher at the edges of the raised beds, eliminating any border effects associated with solarization. Following a 40- to 55-day solarization period, the plastic was painted
Additional keywords: Cyperus esculentus, C. rotundus, Fusarium oxysporum f. sp. lycopersici, Lycopersicon esculentum, Meloidogyne spp., Pseudomonas solanacearum, Rotylenchulus reniformis, Sclerotium rolfsii.
In Florida and other states, field production of fresh market solanaceous crops is based upon high input, intensively managed production systems requiring the use of broad spectrum fumigants to provide economic control of soilborne pests (5). Since the 1970s, methyl bromide has been used almost exclusively, because of its consistent and effective control of soilborne pests under a range of soil moisture and temperature regimes, relatively low cost, and ease of handling $(4,54,56)$. It has been estimated that a ban on the use of methyl bromide would cost producers and consumers in the United States over \$1 billion annually (2) and would reduce production of tomato, pepper, and eggplant in Florida by 69,63 , and $100 \%$, respectively (46). Concerns about the contribution of methyl bromide to the stratospheric depletion of ozone have led to a ban on its production and importation in the United States beginning January $2001(10,13)$.

While several broad spectrum fumigants have been identified as alternatives to methyl bromide $(11,21,35,38)$, use of a single tactic to control soilborne pests still leaves producers vulnerable to future regulatory and marketing policies. For example, half of the soil fumigants used in Florida before 1978 are no longer available, and the remainder have environmental or toxicity problems (4).

Integrated pest management (IPM), which consists of the coordinated use of multiple tactics to maintain pest damage below an economic threshold, offers several advantages over a single tactic approach. Selection of pest management tactics that address the

Corresponding author: D. Chellemi; E-mail address: doc@gnv.ifas.ufl.edu

Publication no. P-1997-0122-01R

(C) 1997 The American Phytopathological Society specific needs and constraints of individual cropping systems eliminates unnecessary pesticide applications and optimizes the performance of existing tactics. IPM fosters the development of selective, biologically based tactics, because the emphasis is on the control of identified pest complexes, not perceived pest threats.

Historically, IPM has not been utilized to control soilborne pests during field production of fresh market solanaceous crops. Preharvest production costs often exceed $\$ 15,000$ per hectare (45), leading producers to take measures that reduce the perceived risk of economic loss from soilborne pests. Assessment of soilborne pest complexes in the field is not routinely practiced, creating uncertainty in the selection of tactics. IPM programs are knowledge intensive; they require additional expertise and supplemental management decisions. The development of cultural pest management tactics that are easy to employ, cost effective, and can enhance the efficacy of chemical, cultural, and biological treatments has been limited (31).

Soil solarization is a pest management tactic that has potential application to IPM systems. It is compatible with and often enhances the performance of various chemical, biological, and cultural treatments $(14,16,17,34,41-44,53)$. Soil solarization has been evaluated in several geographic regions where high value crops are cultivated $(6,20,25,33,37,39)$. Its general contribution to IPM systems has been discussed, but it has not been examined within the constraints of specific crop production systems $(27,49)$.

The objective of this study was to evaluate soil solarization as a component in an IPM program for soilborne pests of tomato. Soil solarization was examined for its adaptability to the production system used for this and other similar crops cultivated in humid 
regions, compatibility with other pest management tactics, and effect on soilborne pests and marketable yield.

\section{MATERIALS AND METHODS}

Characterization of the cropping system. Fall production of fresh market tomato (Lycopersicon esculentum Mill.) in north Florida and south Georgia was used as the model cropping system. Tomatoes are produced on 20-cm-high raised beds covered by white or white on black, low density polyethylene (LDPE) plastic mulch. Beds are prepared and fumigated in June. Tomatoes were transplanted in July and harvested in October. Key soilborne diseases are Fusarium wilt, caused by Fusarium oxysporum Schlechtend.:Fr. f. sp. lycopersici (Sacc.) W.C. Snyder \& H.N. Hans. (races 1, 2, and 3); bacterial wilt, caused by Ralstonia solanacearum; and Southern blight, caused by Sclerotium rolfsii Sacc. Key weed pests are yellow nutsedge (Cyperus esculentus L.) and purple nutsedge (C. rotundus L.). Important phytoparasitic nematodes include the root-knot nematode species Meloidogyne incognita (Kofoid \& White) Chitwood and M. javanica (Treub) Chitwood, reniform nematode Rotylenchulus reniformis Linford \& Oliveira, and stubby-root nematode Paratrichodorus minor (Colbran) Siddiqi.

In 1994, field experiments were conducted on tomato production farms located in Decatur County, GA (Georgia-94), and Gadsden County, FL (Florida-94). In 1995, an experiment was conducted at the North Florida Research and Education Center (Florida-95), Gadsden County. In 1995, large scale field validation studies were implemented in three commercial tomato production fields (validation sites I, II, and III). Soil characteristics are presented in Table 1. All locations had been cropped in tomato for five or more consecutive years except the Florida-95 site, which had been left as weed fallow following previous crops of peanut and tobacco.

Georgia-94 and Florida-94 experiments. Eighteen treatments were arranged in a randomized complete block with four replications per treatment. An incomplete factorial design was used in which 16 treatments consisted of all possible combinations of four soil treatments applied under four types of plastic film. Soil treatments were a mixture of methyl bromide + chloropicrin $(13.1+$ $\left.6.5 \mathrm{~g} / \mathrm{m}^{2}\right)$; metham sodium $\left(5.8 \mathrm{~g} / \mathrm{m}^{2}\right)$; and cabbage residue (Brassica oleracea cv. Constanza) that were dried, shredded, and incorporated into the soil by disking at a rate of $8.0 \mathrm{~kg} / \mathrm{m}^{2}$; and an untreated control. Plastic films included a 30- $\mu \mathrm{m}$-thick, coextruded, white on black LDPE (Edison Plastics Co., Lee Hall, VA); a 30- $\mu$ m-thick, clear LDPE used for solarization (Polydak film; Polyon Barkai Ltd., Kibbutz, Barkai, Israel); a 25 - $\mu$ m-thick, photoselective LDPE used for solarization (IRT film; AEP Industries, Hackensack, NJ); and a 30- $\mu$ m-thick, clear, gas-impermeable film used for solarization (Bromotec film; Lawson Mardon Packaging, Workington, Cumbria, United Kingdom). Two additional treatments consisting of metham sodium $\left(11.6 \mathrm{~g} / \mathrm{m}^{2}\right)$ and methyl bromide + chloropicrin $\left(26.1+13.0 \mathrm{~g} / \mathrm{m}^{2}\right)$ were applied under white on black LDPE.

Each replicate plot was $20 \mathrm{~m}$ in length and consisted of a single raised bed $20 \mathrm{~cm}$ high and $0.9 \mathrm{~m}$ wide. Row orientation was north/south. Beds were spaced $1.8 \mathrm{~m}$ apart. Fertilizer was incorporated into the beds at $212 \mathrm{~kg}$ of N, $65 \mathrm{~kg}$ of P, and $212 \mathrm{~kg}$ of K per hectare, and drip irrigation tubing was placed $5 \mathrm{~cm}$ beneath the soil, $25 \mathrm{~cm}$ from the edge of the bed.

Cabbage was grown and harvested in the plots, and the residue incorporated on 23 and 24 May. Beds were prepared and fumigants applied on 3 and 15 June at the Georgia-94 and Florida-94 sites, respectively. The solarization period was terminated by painting the films with a white, latex-based paint (Kool Grow, Gainesville, FL) mixed at a 6:1 dilution with water and applied through a $\mathrm{CO}_{2}$ backpack sprayer. The painted plastic functioned as a horticultural mulch. Tomato seedlings were transplanted into the plots on 27 July (cv. BHN 189) and 3 August (cv. Solar Set) at the Georgia-94 and Florida-94 sites, respectively.

Precipitation was recorded daily at both sites. Daily ambient temperature readings were obtained from a National Weather Service Reporting Station located in Gadsden County. Hourly soil temperatures were monitored at the Florida-94 site at depths of 10 and $25 \mathrm{~cm}$ using thermocouple sensors. Sensors were placed in the center and $10 \mathrm{~cm}$ from the edge of the beds. An electronic data logger automatically processed and recorded analog signals from the sensors (Omnidata International, Logan, UT). Two tropical storms severely damaged the Florida-94 site, preventing the collection of additional data from that site. Twelve contiguous plants in the center of each replicate plot were harvested from the Georgia-94 site on 7, 18, and 27 October. Fruit were sorted as marketable and unmarketable based upon size and cosmetic appearance.

Florida-95 experiment. Fifteen treatments were arranged in a randomized complete block with four replications per treatment. A factorial design that consisted of five soil treatments $\times$ three plastic films was used. Soil treatments were cabbage residue (cv. Constanza applied at $6.8 \mathrm{~kg} / \mathrm{m}^{2}$ ), pebulate (an herbicide applied at $\left.0.1 \mathrm{~g} / \mathrm{m}^{2}\right)$, a mixture of 1,3-dichloropropene + chloropicrin $(16.2+$ $\left.3.4 \mathrm{~g} / \mathrm{m}^{2}\right)$, a mixture of methyl bromide + chloropicrin $(13.1+6.5$ $\mathrm{g} / \mathrm{m}^{2}$ ), and an untreated control. Plastic films were the same as in 1994 except that the photoselective film was omitted.

Plot dimensions and row orientation were the same as in 1994. Cabbage was grown in another location, harvested, and incorporated into plots on 19 May using the same procedures as in 1994. Pebulate was applied and immediately disked into the soil on 25 May. The remaining soil treatments were applied on 26 May. Fertilizer rates were $196 \mathrm{~kg}$ of $\mathrm{N}, 26 \mathrm{~kg}$ of $\mathrm{P}$, and $163 \mathrm{~kg}$ of $\mathrm{K}$ per hectare. The solarization period was terminated when the plastic was painted. Tomatoes (cv. Solar Set) were transplanted on 31 July. Yield data was collected from twelve contiguous plants in the center of each plot on 11, 18, and 26 October.

Daily rainfall and ambient temperature data were recorded. Hourly temperature changes in bare and solarized soil were monitored in beds located in another location approximately 0.5 $\mathrm{km}$ from the site. Temperatures were recorded at the soil surface and at depths of $5,10,15,20$, and $25 \mathrm{~cm}$ using thermocouple sensors connected to an electronic data logger (Campbell Scientific Inc., Logan, UT).

Validation site I. Five treatments were arranged in a randomized complete block with four replications per treatment. Treatments were soil solarization, soil solarization combined with 1,3dichloropropene + chloropicrin $\left(16.2+3.4 \mathrm{~g} / \mathrm{m}^{2}\right)$, soil solarization combined with methyl bromide $\left(22.4 \mathrm{~g} / \mathrm{m}^{2}\right), 1,3$-dichloropropene + chloropicrin $\left(32.4+6.9 \mathrm{~g} / \mathrm{m}^{2}\right)$ applied under white plastic, and methyl bromide $\left(45.0 \mathrm{~g} / \mathrm{m}^{2}\right)$ applied under white plastic. Soil solarization treatments were performed using clear, $25-\mu \mathrm{m}$-thick LDPE plastic (Polydak film). Each replicate plot consisted of three rows $182 \mathrm{~m}$ in length. Row-spacing orientation, bed dimensions, and plant spacings were the same as in previous experiments.

TABLE 1. Characteristics of field soils at the time of solarization and soil treatments

\begin{tabular}{|c|c|c|c|c|c|}
\hline Site & $\mathrm{pH}$ & $\begin{array}{l}\text { Soil water } \\
\text { content } \\
(\%)^{\mathrm{y}}\end{array}$ & $\begin{array}{c}\text { Organic } \\
\text { matter } \\
(\%)\end{array}$ & $\begin{array}{c}\text { Percent } \\
\text { sand-silt-clay } \\
(\%)\end{array}$ & Soil class \\
\hline Georgia-94 & 6.6 & 9.9 & 1.1 & $84.0-6.0-10.0$ & Kandiudult $^{\mathrm{z}}$ \\
\hline Florida-94 & 5.1 & 6.1 & 0.5 & $88.5-4.5-7.0$ & Kandiudult \\
\hline Validation site I & 6.3 & 9.8 & 0.4 & $86.0-5.5-8.5$ & Kandiudult \\
\hline Florida-95 & 4.7 & 7.7 & 1.5 & $88.5-4.0-7.5$ & Kandiudult \\
\hline Validation site II & 6.2 & 10.3 & 0.8 & $87.0-6.5-6.5$ & Kandiudult \\
\hline Validation site III & 6.1 & 9.1 & 1.0 & $80.5-9.5-10.0$ & Kandiudult \\
\hline
\end{tabular}

${ }^{y}$ Water content expressed as a percentage of the mass of dry soil (gravimetric method).

${ }^{\mathrm{z}}$ Ultisol with profiles similar to paleudults, but containing higher amounts of kaolinitic clay. 
Treatments were applied on 9 June. The solarization period was terminated by painting the plastic, and tomatoes (cv. BHN 189) were transplanted on 19 July. Yield data were obtained by harvesting 12 contiguous plants from the middle row of each replicate plot on 28 September; 10, 19, and 25 October; and 1 November. Daily precipitation and ambient temperature data were obtained from a National Weather Service Reporting Station located $9 \mathrm{~km}$ from the study site.

Validation sites II and III. Unreplicated field plots were established on two additional commercial tomato production farms in 1995. Row orientation was north/south in site II and east/west in site III. Soil solarization was performed on 12 rows $210 \mathrm{~m}$ in length (0.48 ha) in site II using 30- $\mu$ m-thick LDPE (Polydak film) and on seven rows $324 \mathrm{~m}$ in length (0.42 ha) in site III using 25$\mu \mathrm{m}$-thick LDPE (Polydak film). Rows adjacent to the solarization

TABLE 2. Environmental conditions during solarization periods

\begin{tabular}{lcccc}
\hline & & \multicolumn{3}{c}{ Number of days } \\
\cline { 3 - 5 } & $\begin{array}{c}\text { Total } \\
\text { precipitation } \\
\text { (cm) }\end{array}$ & $\begin{array}{c}\text { Solarization } \\
\text { period }\end{array}$ & $\begin{array}{c}\text { Precipitation } \\
\text { occurred }\end{array}$ & $\begin{array}{c}\text { Maximum } \\
\text { ambient } \\
\text { temperature } \\
\geq 35^{\circ} \mathrm{C}\end{array}$ \\
\hline Georgia-94 & 46.0 & 49 & 30 & 0 \\
Florida-94 & 38.4 & 48 & 31 & 0 \\
Florida-95 & 30.1 & 55 & 17 & 6 \\
Validation site I & 17.4 & 40 & 12 & 6 \\
Validation site II & NA & 40 & NA & 6 \\
Validation site III & NA & 36 & NA & 5 \\
\hline
\end{tabular}

${ }^{\mathrm{z}}$ Not available.

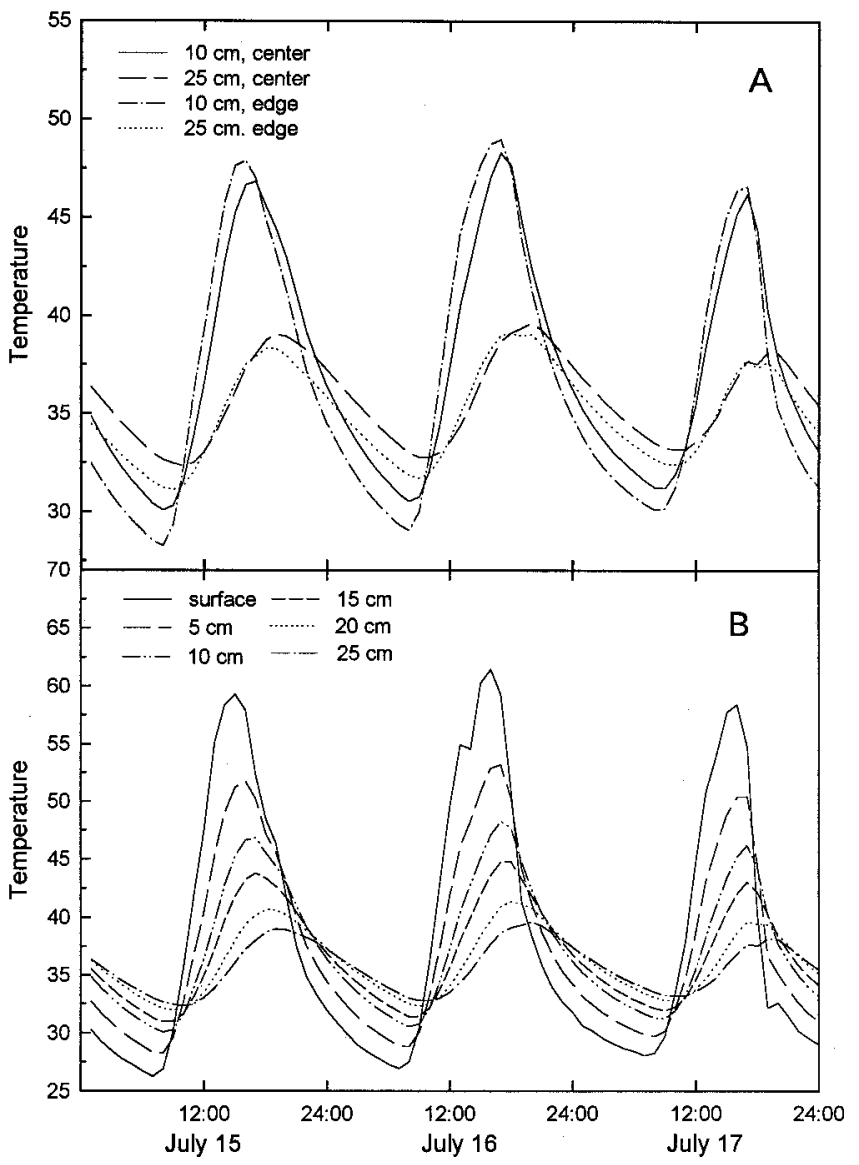

Fig. 1. Hourly fluctuations in soil temperatures over a 3-day period at the Florida-95 site. A, Comparison among temperatures at 10 and $25 \mathrm{~cm}$ depths in the center and $10 \mathrm{~cm}$ from the edge of a 0.9-m-wide, 20-cm-high bed covered by clear, low density polyethylene plastic. B, Temperature profile at various depths within the center of the raised bed. treatment were fumigated with methyl bromide $\left(45 \mathrm{~g} / \mathrm{m}^{2}\right)$ and covered with a white over black, coextruded LDPE (Edison Plastics Co.). Soil disinfestation treatments were applied on 9 June in site II and 13 June in site III. The solarization period was terminated by painting the plastic white. Tomato seedlings (cv. Solar Set) were transplanted into all treatments. Yield data were obtained by harvesting 12 contiguous plants from four different locations each within both the solarized and methyl bromide-treated areas.

Assessment of pest control. In locations where Cyperus spp. were present, assessment of control was made by counting the number of plants emerging through the plastic over a 12-m-long section and computed as an average per $0.27 \mathrm{~m}^{2}$ of bed. Ratings were taken at the end of the solarization period, prior to transplanting. In locations where symptoms of soilborne diseases were present, disease incidence was assessed by counting the number of plants with symptoms in each replicate plot and dividing by the total number of plants present in each replicate plot. Soil samples for nematode analysis were collected by removing and combining soil cores $2.5 \mathrm{~cm}$ wide and $20 \mathrm{~cm}$ deep from the root zone of each of six plants per plot. Nematodes were extracted from $100-\mathrm{cm}^{3}$ soil subsamples with a modified sieving and centrifugation procedure (28), and then identified and counted. In locations where root galling from Meloidogyne spp. was present, root systems from five plants in each replicate plot were removed and rated for root galling on a 0 to 5 scale (52) in which $0=$ no galls per root system, $1=$ one to two galls per root system, $2=$ three to 10 galls per root system, $3=11$ to 30 galls per root system, $4=31$ to 100 galls per root system, and $5=$ more than 100 galls per root system.

Evaluation of soil heating under raised beds. Soil temperatures under a flat surface and $20-\mathrm{cm}$ raised beds were recorded to obtain information on the efficiency of strip solarization performed on raised beds. The comparison was made between 30 August and 23 September 1995 in a location near the Florida-95

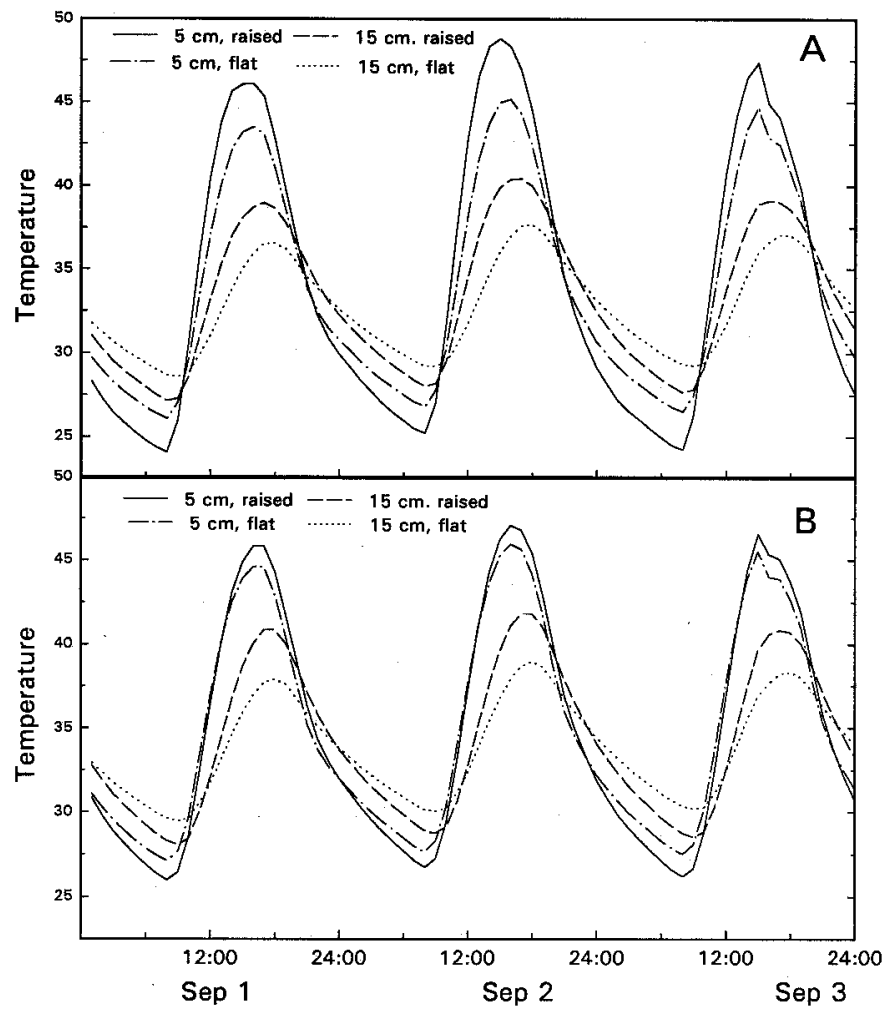

Fig. 2. Hourly fluctuations in soil temperatures at 5 and $15 \mathrm{~cm}$ depths over a 3-day period under a 0.9 -m-wide sheet of clear, low density polyethylene plastic stretched over a flat surface or a $20-\mathrm{cm}$-high bed. A, Soil temperatures at $10 \mathrm{~cm}$ from the east edge of the plastic strip. B, Soil temperatures from the center of the plastic strip. 
site. A $0.9 \times 10.0$-m sheet of clear, $25-\mu$ m-thick, LDPE (Polydak film) was stretched over a flat soil surface and a over raised bed $20 \mathrm{~cm}$ high and $0.9 \mathrm{~m}$ wide. Soil moisture at initiation of the comparison was $15.6 \%$. Daily precipitation and ambient temperature data were recorded at the site. Hourly changes in soil temperatures were monitored in the raised and flat beds at 5 and $15 \mathrm{~cm}$ depths using thermocouple sensors connected to an electronic data logger (Campbell Scientific Inc.). Row orientation was north/south. Soil temperatures were monitored $10 \mathrm{~cm}$ from the edge on the west and east side of the bed and in the center of the bed.

Statistical analysis. Nematode counts were log-transformed $\left(\log _{10}[x+1]\right)$ and disease incidence data were transformed using the arc sine transformation $\left(\sin ^{-1}\right.$ square root $x$ ) prior to analysis. Analysis of variance was performed with PROC GLM of SAS (release 6.04 for personal computers; SAS Institute, Cary, NC) for all data except nematode density counts, which were analyzed using MSTAT (Michigan State University, East Lansing). The Waller-Duncan $k$-ratio $t$ test was used to compare all treatment means except for nematode density counts, which were compared using Duncan's multiple range test.

\section{RESULTS}

Site conditions. Soil water content, expressed as a percentage of the mass of dry soil, ranged from 6.1 to $10.3 \%$ at the onset of solarization and fumigation treatments (Table 1). The solarization periods ranged from 36 to 55 days (Table 2). In 1994, precipitation was recorded on at least 30 different days in the solarization period at both sites (Table 2). In 1995, precipitation occurred on 12 and 17 different days in the solarization period at the Florida-95 site and validation site I, respectively.

Soil temperatures. At the Florida-94 site, the maximum temperature at a $10 \mathrm{~cm}$ depth was $41.5^{\circ} \mathrm{C}$ under bare soil and 41.8 , 45.7 , and $49.2^{\circ} \mathrm{C}$ under white, photoselective, and clear plastic, respectively. At a $25 \mathrm{~cm}$ depth, the maximum soil temperature was $34.6^{\circ} \mathrm{C}$ under bare soil and $34.7,37.3$, and $38.0^{\circ} \mathrm{C}$ under white, photoselective, and clear plastic, respectively. Addition of cabbage residue did not increase soil temperature.

At the Florida- 95 site, the maximum soil temperature at a $10 \mathrm{~cm}$ depth was $42.4^{\circ} \mathrm{C}$ under bare soil and $48.7^{\circ} \mathrm{C}$ under clear LDPE. At a $25 \mathrm{~cm}$ depth, the maximum soil temperature was $35.1^{\circ} \mathrm{C}$ under bare soil and $40.3^{\circ} \mathrm{C}$ under clear LDPE. Soil temperatures near the edge of the plastic were 1 to $2^{\circ} \mathrm{C}$ higher than in the center (Fig. 1A). Under clear LDPE, the maximum soil temperature declined rapidly from $61.3^{\circ} \mathrm{C}$ at the surface to $53.2^{\circ} \mathrm{C}$ at a $5 \mathrm{~cm}$ depth (Fig. 1B). At depths of 5 and $15 \mathrm{~cm}$, higher soil temperatures were achieved when solarization was performed on a raised bed as opposed to on a flat surface (Fig. 2A and B). The differences were more pronounced at the edges of the bed than in the center. On a raised bed, temperatures at the edges often exceeded those in the center (Fig. 2).

TABLE 3. Effects ${ }^{\mathrm{w}}$ of soil treatments and solarization with various plastic films on soilborne pests and yield of fresh market tomato at the Georgia-94 site

\begin{tabular}{|c|c|c|c|c|c|c|}
\hline \multirow[b]{2}{*}{ Soil treatment } & \multirow[b]{2}{*}{ Rate per $\mathrm{m}^{2}$} & \multicolumn{4}{|c|}{ Plastic film ${ }^{\mathrm{x}, \mathrm{y}}$} & \multirow[b]{2}{*}{ Mean ${ }^{y}$} \\
\hline & & Clear, GI & White & Clear & IRT & \\
\hline \multicolumn{7}{|l|}{ Fusarium wilt } \\
\hline None & $\ldots$ & $0.0 \mathrm{~d}$ & $7.2 \mathrm{a}$ & $0.0 \mathrm{~d}$ & $1.0 \mathrm{~cd}$ & 2.0 \\
\hline Metham-Na & $5.8 \mathrm{~g}$ & $0.0 \mathrm{~d}$ & $3.8 \mathrm{bc}$ & $0.9 \mathrm{~cd}$ & $0.9 \mathrm{~cd}$ & 1.4 \\
\hline $\mathrm{MBC}^{\mathrm{z}}$ & $13.1+6.5 \mathrm{~g}$ & $0.0 \mathrm{~d}$ & $0.0 \mathrm{~d}$ & $0.0 \mathrm{~d}$ & $0.0 \mathrm{~d}$ & 0.0 \\
\hline Mean & & 0.2 & 4.2 & 0.2 & 1.0 & \\
\hline None & $\ldots$ & 4.4 & 15.6 & 20.7 & 4.9 & 11.4 \\
\hline Cabbage & $8.0 \mathrm{~kg}$ & 10.0 & 20.5 & 2.9 & 23.6 & 14.2 \\
\hline Metham-Na & $5.8 \mathrm{~g}$ & 9.2 & 18.5 & 33.4 & 19.4 & 20.1 \\
\hline MBC & $13.1+6.5 \mathrm{~g}$ & 19.2 & 5.0 & 9.6 & 10.1 & 11.0 \\
\hline Mean & & 10.7 & 14.9 & 16.6 & 14.5 & \\
\hline \multicolumn{7}{|c|}{ Paratrichodorus minor } \\
\hline \multicolumn{7}{|l|}{ Cyperus species } \\
\hline None & $\ldots$ & $0.1 \mathrm{~b}$ & $12.0 \mathrm{a}$ & $0.1 \mathrm{~b}$ & $<0.1 \mathrm{~b}$ & 3.1 \\
\hline Cabbage & $8.0 \mathrm{~kg}$ & $0.2 \mathrm{~b}$ & $3.1 \mathrm{~b}$ & $<0.1 \mathrm{~b}$ & $0.5 \mathrm{~b}$ & 1.0 \\
\hline Metham-Na & $5.8 \mathrm{~g}$ & $0.1 \mathrm{~b}$ & $3.0 \mathrm{~b}$ & $<0.1 \mathrm{~b}$ & $0.2 \mathrm{~b}$ & 0.8 \\
\hline MBC & $13.1+6.5 \mathrm{~g}$ & $<0.1 \mathrm{~b}$ & $0.5 \mathrm{~b}$ & $<0.1 \mathrm{~b}$ & $0.2 \mathrm{~b}$ & 0.2 \\
\hline Mean & & 0.1 & 4.6 & 0.1 & 0.2 & \\
\hline \multicolumn{7}{|l|}{ Marketable yield } \\
\hline None & $\ldots$ & $45.4 \mathrm{a}$ & $23.2 \mathrm{c}$ & $48.5 \mathrm{a}$ & $42.6 \mathrm{ab}$ & 39.9 \\
\hline Cabbage & $8.0 \mathrm{~kg}$ & $51.7 \mathrm{a}$ & $28.7 \mathrm{c}$ & $50.9 \mathrm{a}$ & $32.2 \mathrm{bc}$ & 40.9 \\
\hline Metham-Na & $5.8 \mathrm{~g}$ & $53.7 \mathrm{a}$ & $46.2 \mathrm{a}$ & $42.0 \mathrm{ab}$ & $45.7 \mathrm{a}$ & 46.9 \\
\hline MBC & $13.1+6.5 \mathrm{~g}$ & $46.7 \mathrm{a}$ & $49.3 \mathrm{a}$ & $47.0 \mathrm{a}$ & $46.0 \mathrm{a}$ & 47.2 \\
\hline
\end{tabular}

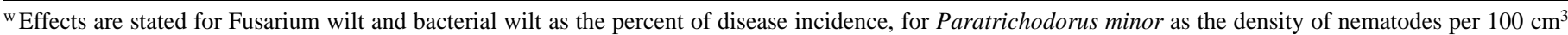
of soil (samples collected 62 days after transplanting), for Cyperus species as the number of plants per $0.27-\mathrm{m}^{2}$ area that emerged through the plastic at the termination of the solarization period, and for marketable yield as metric tons per hectare.

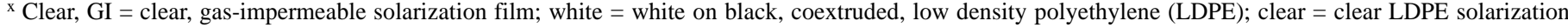
film; and IRT = a photoselective solarization film with transmission values of $15 \%$ for photosynthetically active radiation and $23 \%$ for total radiation.

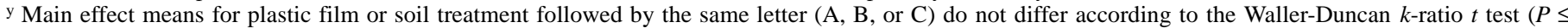
0.05). Means for the interaction of soil treatment and plastic film followed by the same letter (a, b, c, or d) do not differ according to the Waller-Duncan $k$-ratio $t$ test $(P \leq 0.05)$.

${ }^{\mathrm{z}}$ A mixture of methyl bromide + chloropicrin. 
Soilborne diseases. There was a significant interaction between the effects of soil treatments and plastic film on the incidence of Fusarium wilt at the Georgia-94 site (Table 3). Plots receiving soil solarization or methyl bromide had significantly lower levels of disease than plots receiving metham sodium. Doubling the rate of metham sodium did not result in lower levels of disease (Table 4). Fusarium wilt was not detected at the other sites.

At the Georgia-94 site, neither soil treatment nor plastic had a significant effect on the incidence of bacterial wilt (Table 3). Doubling the rate of methyl bromide + chloropicrin resulted in significantly higher levels of bacterial wilt (Table 4). Doubling the rate of metham sodium did not affect the level of disease. Bacterial wilt was observed in validation sites I and II, but the incidence was below $1 \%$.

Soil treatment and plastic film had a significant effect on the incidence of Southern blight at the Florida-95 site (Table 5). Disease levels were higher in the plots receiving only cabbage amendment and were lower in plots receiving soil solarization. In validation site II, the incidence of Southern blight was $<0.1 \%$ in the solarized area and $3.7 \%$ in the areas treated with methyl bromide (Table 6).

Yellow and purple nutsedge. A significant interaction between soil treatment and plastic was observed at the Georgia-94 and Florida-95 sites. At the Georgia-94 site, nutsedge pressure was less severe, and both soil solarization and methyl bromide + chloropicrin provided significant control of mixed populations of yellow and purple nutsedge (Table 3). Doubling the dosage of methyl bromide + chloropicrin or metham sodium did not increase the level of control (Table 4). In the Florida-95 site, nutsedge pressure was more intense, and only treatments with solarization provided significant levels of control (Table 5).

Phytoparasitic nematodes. Soil treatment and plastic had a significant effect on the density of Paratrichodorus minor at the

TABLE 4. Contrast among treatments at the Georgia-94 site under white plastic receiving reduced and full rates of methyl bromide + chloropicrin (MBC) or metham sodium (Metham-Na)

\begin{tabular}{|c|c|c|c|}
\hline Treatment & Rate per $\mathrm{m}^{2}$ & $\begin{array}{c}\text { Control } \\
\text { assessment }\end{array}$ & $P R>F^{\mathrm{z}}$ \\
\hline \multicolumn{4}{|l|}{ Marketable yield } \\
\hline Metham-Na & $5.8 \mathrm{~g}$ & 46.3 & 0.76 \\
\hline Metham-Na & $11.6 \mathrm{~g}$ & 41.9 & \\
\hline $\mathrm{MBC}$ & $13.1+6.5 \mathrm{~g}$ & 49.3 & 0.08 \\
\hline MBC & $26.2+13.0 \mathrm{~g}$ & 39.8 & \\
\hline \multicolumn{4}{|l|}{ Cyperus species } \\
\hline Metham-Na & $5.8 \mathrm{~g}$ & 3.0 & 0.99 \\
\hline Metham-Na & $11.6 \mathrm{~g}$ & 7.7 & \\
\hline $\mathrm{MBC}$ & $13.1+6.5 \mathrm{~g}$ & 0.5 & 0.91 \\
\hline $\mathrm{MBC}$ & $26.2+13.0 \mathrm{~g}$ & 0.3 & \\
\hline \multicolumn{4}{|l|}{ Bacterial wilt } \\
\hline Metham-Na & $5.8 \mathrm{~g}$ & 10.0 & 0.66 \\
\hline Metham-Na & $11.6 \mathrm{~g}$ & 18.5 & \\
\hline MBC & $13.1+6.5 \mathrm{~g}$ & 5.0 & 0.05 \\
\hline $\mathrm{MBC}$ & $26.2+13.0 \mathrm{~g}$ & 13.5 & \\
\hline \multicolumn{4}{|l|}{ Fusarium wilt } \\
\hline Metham-Na & $5.8 \mathrm{~g}$ & 3.8 & 1.00 \\
\hline Metham-Na & $11.6 \mathrm{~g}$ & 5.7 & \\
\hline $\mathrm{MBC}$ & $13.1+6.5 \mathrm{~g}$ & 0.0 & 0.98 \\
\hline $\mathrm{MBC}$ & $26.2+13.0 \mathrm{~g}$ & 1.0 & \\
\hline \multicolumn{4}{|c|}{ Paratrichodorus minor } \\
\hline Metham-Na & $5.8 \mathrm{~g}$ & 50.0 & 0.70 \\
\hline Metham-Na & $11.6 \mathrm{~g}$ & 58.0 & \\
\hline MBC & $13.1+6.5 \mathrm{~g}$ & 62.2 & 0.20 \\
\hline $\mathrm{MBC}$ & $26.2+13.0^{\circ}$ & 38.2 & \\
\hline
\end{tabular}

y Assessment for marketable yield is the yield in metric tons per hectare, for Cyperus species is the number of plants emerging per $0.27-\mathrm{m}^{2}$ area, for bacterial wilt and Fusarium wilt is the percent of disease incidence, and for Paratrichodorus minor is the number of nematodes per $100 \mathrm{~cm}^{3}$ of soil.

z The significance probability value associated with the $F$ value.
Georgia-94 site (Table 3). Significantly lower densities of Paratrichodorus minor were observed in the plots receiving solarization. Doubling the dosage of fumigants did not affect the density of Paratrichodorus minor (Table 4). In the Florida-95 site, soil treatment and plastic also had a significant effect on the density of Paratrichodorus minor (Table 7).

The density of Paratrichodorus minor was lower in areas receiving soil solarization in validation sites II and III (Table 6), but not in validation site I (Table 8). In all five sites examined, application of methyl bromide + chloropicrin failed to reduce the density of Paratrichodorus minor (Tables 3, 4, 6, 7, and 8).

A significant interaction between soil treatment and plastic was observed for the severity of root galling by Meloidogyne spp. at the Florida-95 site (Table 5). Treatments receiving methyl bromide + chloropicrin or the combination of soil solarization, 1,3dichloropropene + chloropicrin, and a gas-impermeable plastic had significantly lower levels of root galling. Soil treatment had a significant effect on the density of Meloidogyne spp. at the Florida-95 site (Table 7). At validation site I, treatments did not significantly impact the density of Meloidogyne spp. (Table 8).

At the Florida-95 site, the density of $R$. reniformis was significantly lower in plots receiving methyl bromide + chloropicrin or 1,3-dichloropropene + chloropicrin (Table 7). The density of $R$. reniformis in validation site III was lower in plots treated with methyl bromide (Table 6).

Significant reductions in Criconemella and Helicotylenchus spp. were achieved using soil solarization, methyl bromide + chloropicrin, and 1,3-dichloropropene + chloropicrin (Table 7).

Marketable yield. A significant interaction between soil treatment and plastic was observed at the Georgia-94 and Florida-95 sites. No significant difference in yield was observed between plots receiving methyl bromide + chloropicrin or soil solarization at the Georgia-94 site except for plots that received cabbage + solarization using the photoselective plastic, which was significantly lower (Table 3). Doubling the rate of metham sodium did not affect yield. Doubling the rate of methyl bromide + chloropicrin resulted in significantly lower yields, because of the increased incidence of bacterial wilt. At the Florida-95 site, the interactions between plastic and soil treatment were complex. Yields in plots receiving solarization, solarization and methyl bromide + chloropicrin, or solarization and 1,3-dichloropropene + chloropicrin were significantly higher than yields in plots receiving soil treatments applied under white plastic (Table 5). At validation site I, yields in plots treated with a high rate of 1,3-dichloropropene + chloropicrin were significantly higher than yields in plots receiving only solarization (Table 8). At validation sites II and III, yields in areas treated with soil solarization were similar to yields in areas treated with methyl bromide (Table 6).

\section{DISCUSSION}

Soil solarization has been traditionally considered a soil disinfestation technique suitable for arid climates. In recent years, reports of its application potential in humid regions characterized by abundant rainfall and cloud cover have been published $(8,9,19$, $20,30,33,34,37,39,43,44)$. In this study, precipitation occurred on 30 to $64 \%$ of the solarization days, yet marketable yields of fresh market tomato in plots receiving soil solarization were similar or greater than yields in plots receiving methyl bromide. In the large scale field plots, yields in areas receiving solarization were similar to yields in methyl bromide-treated areas, validating the application potential of soil solarization.

Although the yield potential of treatments receiving soil solarization was demonstrated, it should be noted that not all soilborne pests were suppressed when soil solarization was employed alone. Soil solarization failed to reduce densities of $R$. reniformis and Meloidogyne spp. and the severity of root galling in the Florida-95 experiment and in validation site I. In the Florida-95 site, a mix- 
ture of $M$. incognita and $M$. javanica was identified. Significant reductions in $M$. javanica and $M$. incognita by soil solarization have been reported $(1,39,40,48,51)$. Reductions in $R$. reniformis by soil solarization also have been reported $(1,6,9,26)$. The lack of control of Meloidogyne spp. and $R$. reniformis may be due to nematode recolonization of treated soil. In several studies in which soil so- larization suppressed initial populations, recolonization was shown to occur $(1,6,26,40)$. At the Florida-95 site, nematode samples were not collected until 80 days after transplanting, allowing sufficient time for recolonization to occur. Strip solarization, in which $50 \%$ of the field was untreated, may have further enhanced recolonization. In a previous study performed in the same production

TABLE 5. Effects ${ }^{\mathrm{u}}$ of soil treatments and solarization with various plastic films on soilborne pests and yield of fresh market tomato at the Florida-95 site

\begin{tabular}{|c|c|c|c|c|c|}
\hline \multirow[b]{2}{*}{ Soil treatment } & \multirow[b]{2}{*}{ Rate per $\mathrm{m}^{2}$} & \multicolumn{3}{|c|}{ Plastic film ${ }^{\mathrm{v}, \mathrm{w}}$} & \multirow[b]{2}{*}{ Mean $^{w}$} \\
\hline & & Clear, GI & White & Clear & \\
\hline \multicolumn{6}{|l|}{ Southern blight ${ }^{\mathrm{x}}$} \\
\hline None & $\ldots$ & 2.0 & 11.0 & 4.2 & $5.8 \mathrm{~B}$ \\
\hline Pebulate & $0.1 \mathrm{~g}$ & 5.6 & 8.5 & 4.0 & $6.1 \mathrm{~B}$ \\
\hline Cabbage & $6.8 \mathrm{~kg}$ & 9.5 & 19.2 & 5.5 & $11.4 \mathrm{~A}$ \\
\hline 1,3-DCPC & $16.2+3.4 \mathrm{~g}$ & 3.2 & 4.2 & 1.8 & $3.1 \mathrm{~B}$ \\
\hline $\mathrm{MBC}^{\mathrm{z}}$ & $13.1+6.5 \mathrm{~g}$ & 3.2 & 2.0 & 3.0 & $2.8 \mathrm{~B}$ \\
\hline Mean & & $4.8 \mathrm{~B}$ & $9.0 \mathrm{~A}$ & $3.7 \mathrm{~B}$ & \\
\hline \multicolumn{6}{|l|}{ Root gall ratings } \\
\hline None & $\ldots$ & $3.6 \mathrm{abcd}$ & $2.8 \mathrm{def}$ & 3.2 bcde & 3.2 \\
\hline Pebulate & $0.1 \mathrm{~g}$ & $4.0 \mathrm{abc}$ & $4.0 \mathrm{abc}$ & $4.5 \mathrm{a}$ & 4.2 \\
\hline Cabbage & $6.8 \mathrm{~kg}$ & 3.0 cde & $4.5 \mathrm{a}$ & $4.3 \mathrm{ab}$ & 3.9 \\
\hline 1,3-DCPC & $16.2+3.4 \mathrm{~g}$ & $0.8 \mathrm{gh}$ & $2.4 \mathrm{ef}$ & $1.8 \mathrm{fg}$ & 1.6 \\
\hline $\mathrm{MBC}$ & $13.1+6.5 \mathrm{~g}$ & $0.2 \mathrm{~h}$ & $0.4 \mathrm{~h}$ & $0.8 \mathrm{gh}$ & 0.4 \\
\hline Mean & & 2.3 & 2.8 & 2.9 & \\
\hline \multicolumn{6}{|l|}{ Cyperus species } \\
\hline None & $\ldots$ & $0.1 \mathrm{c}$ & $33.4 \mathrm{~b}$ & $0.9 \mathrm{c}$ & 11.4 \\
\hline Pebulate & $0.1 \mathrm{~g}$ & $0.0 \mathrm{c}$ & $25.2 \mathrm{~b}$ & $0.6 \mathrm{c}$ & 8.6 \\
\hline Cabbage & $6.8 \mathrm{~kg}$ & $0.0 \mathrm{c}$ & $56.1 \mathrm{a}$ & $0.6 \mathrm{c}$ & 18.9 \\
\hline 1,3-DCPC & $16.2+3.4 \mathrm{~g}$ & $0.0 \mathrm{c}$ & $61.6 \mathrm{a}$ & $0.5 \mathrm{c}$ & 20.7 \\
\hline $\mathrm{MBC}$ & $13.1+6.5 \mathrm{~g}$ & $0.0 \mathrm{c}$ & $48.6 \mathrm{a}$ & $0.4 \mathrm{c}$ & 16.3 \\
\hline Mean & & $<0.1$ & 45.0 & 0.6 & \\
\hline \multicolumn{6}{|l|}{ Marketable yield } \\
\hline None & $\ldots$ & $42.8 \mathrm{ab}$ & $17.5 \mathrm{efg}$ & $30.3 \mathrm{bcd}$ & 30.2 \\
\hline Pebulate & $0.1 \mathrm{~g}$ & 27.0 cde & $6.8 \mathrm{~g}$ & $35.2 \mathrm{bc}$ & 23.0 \\
\hline Cabbage & $6.8 \mathrm{~kg}$ & $30.8 \mathrm{bcd}$ & $11.2 \mathrm{fg}$ & $41.1 \mathrm{ab}$ & 27.7 \\
\hline 1,3-DCPC & $16.2+3.4 \mathrm{~g}$ & $36.0 \mathrm{bc}$ & $20.6 \mathrm{def}$ & $37.7 \mathrm{abc}$ & 31.4 \\
\hline $\mathrm{MBC}$ & $13.1+6.5 \mathrm{~g}$ & $50.2 \mathrm{a}$ & $14.1 \mathrm{fg}$ & $41.3 \mathrm{ab}$ & 35.2 \\
\hline Mean & & 37.3 & 14.1 & 37.4 & \\
\hline
\end{tabular}

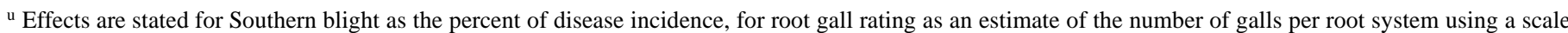
of 0 to 5 in which $0=$ no galls and $5=>100$ galls (52), for Cyperus species as the number of plants per $0.27-\mathrm{m}^{2}$ area emerging through the plastic at the termination of the solarization period, and for marketable yield as metric tons per hectare.

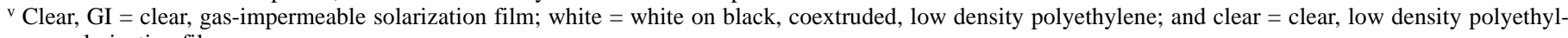
ene solarization film.

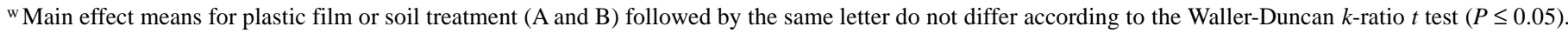
Means for the interaction of soil treatment and plastic film followed by the same letter (a to h) do not differ according to the Waller-Duncan $k$-ratio $t$ test $(P \leq$ $0.05)$.

x Incidence of Southern blight caused by Sclerotium rolfsii.

y A mixture of 1,3-dichloropropene + chloropicrin.

${ }^{\mathrm{z}}$ A mixture of methyl bromide + chloropicrin.

TABLE 6. Effect of soil solarization on soilborne pests and marketable yield of tomato in validation sites II and III

\begin{tabular}{|c|c|c|c|c|c|c|c|c|}
\hline Plastic $^{r}$ & $\begin{array}{c}\text { Soil } \\
\text { treatment }\end{array}$ & Rate $^{\mathrm{s}}$ & Southern blight ${ }^{t}$ & $\begin{array}{c}\text { Paratrichodorus } \\
\text { minor }^{\mathrm{u}}\end{array}$ & $\begin{array}{l}\text { Rotylenchulus } \\
\text { reniformis }\end{array}$ & $\begin{array}{l}\text { Meloidogyne } \\
\text { species }^{\mathrm{u}}\end{array}$ & Root gall index ${ }^{v}$ & $\begin{array}{c}\text { Marketable } \\
\text { yield }^{\mathrm{w}}\end{array}$ \\
\hline \multicolumn{9}{|c|}{ Validation site II $^{\mathrm{x}}$} \\
\hline Clear & None & $\ldots$ & $<0.1 \%$ & 11.8 & $\ldots$ & 0.5 & 0.3 & 54.4 \\
\hline White & $\mathrm{MBC}^{\mathrm{y}}$ & $45 \mathrm{~g}$ & $3.7 \%$ & 35.5 & $\ldots$ & 0.0 & 0.2 & 50.9 \\
\hline \multicolumn{9}{|c|}{ Validation site III $^{\mathrm{z}}$} \\
\hline Clear & None & $\ldots$ & $\ldots$ & 31.8 & 44.5 & $\ldots$ & $\ldots$ & 60.6 \\
\hline White & $\mathrm{MBC}$ & $45 \mathrm{~g}$ & $\ldots$ & 45.0 & 0.5 & $\ldots$ & $\ldots$ & 61.4 \\
\hline
\end{tabular}

${ }_{\mathrm{r}}$ Clear = clear, low density polyethylene solarization film and white $=$ white on black, coextruded low density polyethylene.

s Per square meter.

t Disease incidence.

u Number of nematodes per $100 \mathrm{~cm}^{3}$ of soil.

${ }^{v}$ Estimates of the number of galls per root system using a scale of 0 to 5 in which $0=$ no galls and $5=>100$ galls $(52)$.

${ }^{\mathrm{w}}$ Metric tons per hectare.

x Solarization performed on 0.48 ha (12 rows, $210 \mathrm{~m}$ long).

y A 98:2 mixture of methyl bromide + chloropicrin.

z Solarization performed on 0.42 ha ( 7 rows, $324 \mathrm{~m}$ long). 
region, broadcast solarization provided season-long reduction in populations of $R$. reniformis (9). Evidence for late-season recolonization is supported by the fact that although high numbers of $R$. reniformis, Meloidogyne spp., and severe root galling were found in the Florida-95 experiment and in validation sites I and II, yield of marketable fruit was not affected. Several studies in which recolonization occurred also showed no effect of the nematode damage on yield $(1,26)$. Strip solarization, as practiced here, was ef-

TABLE 7. Effects of soil treatments and solarization using various plastic films on the density of phytoparasitic nematodes per $100 \mathrm{~cm}^{3}$ of soil at the Florida-95 site $^{\mathrm{V}}$

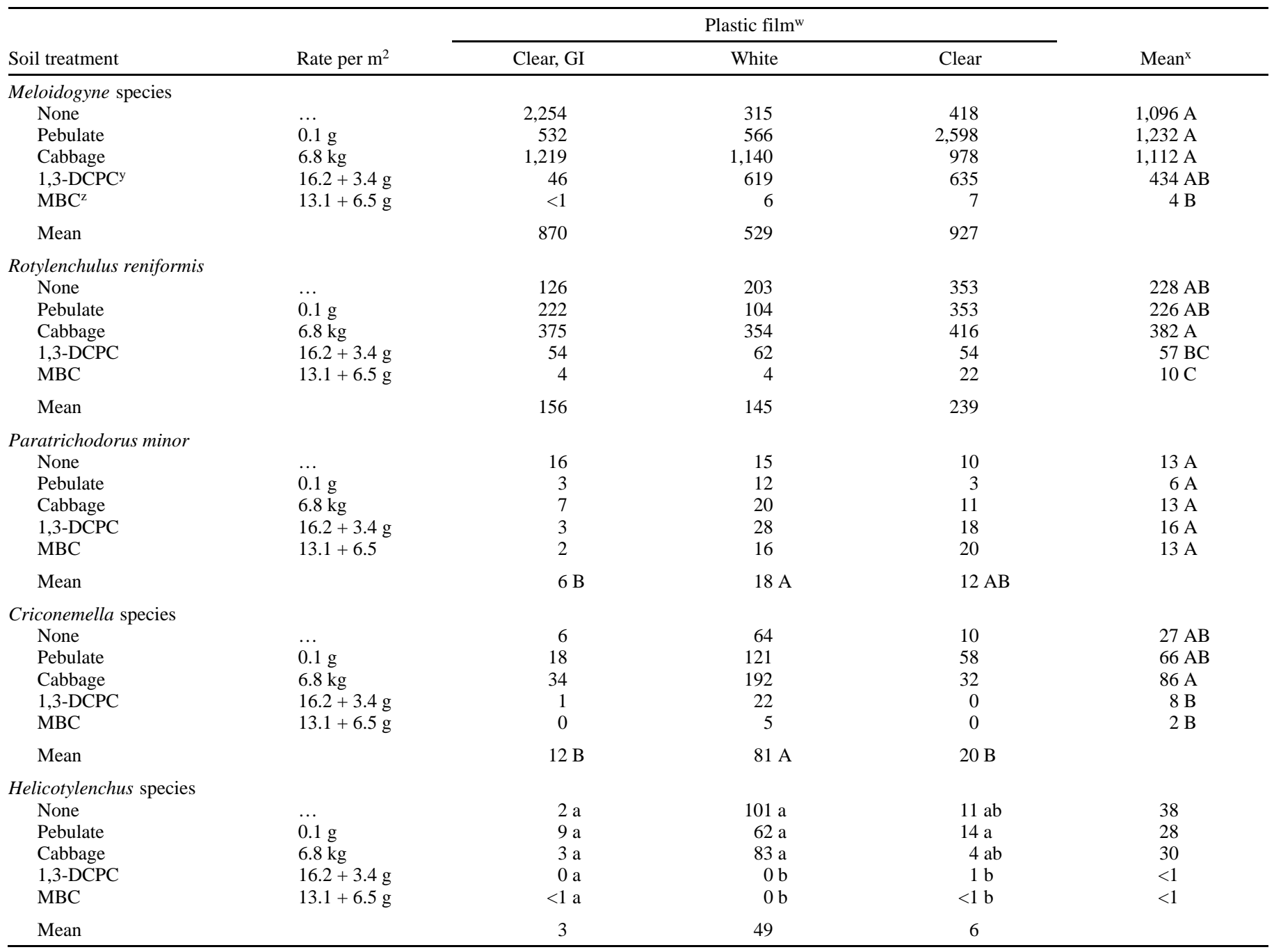

${ }^{v}$ Samples collected 80 days after transplanting.

${ }^{\text {w } C l e a r, ~ G I ~=~ c l e a r, ~ g a s-i m p e r m e a b l e ~ s o l a r i z a t i o n ~ f i l m ; ~ w h i t e ~=~ w h i t e ~ o n ~ b l a c k, ~ c o e x t r u d e d, ~ l o w ~ d e n s i t y ~ p o l y e t h y l e n e ; ~ a n d ~ c l e a r ~=~ c l e a r, ~ l o w ~ d e n s i t y ~ p o l y e t h y l-~}$ ene solarization film.

${ }^{x}$ Main effect means for plastic film or soil treatment (A, B, and C) followed by the same letter do not differ $(P \leq 0.05)$ according to Duncan's multiple range test. Means for interactions between plastic film and soil treatments followed by the same letter (a and b) do not differ $(P \leq 0.05)$ according to Duncan's multiple range test.

y A mixture of 1,3-dichloropropene + chloropicrin.

${ }^{\mathrm{z}}$ A mixture of methyl bromide + chloropicrin.

TABLE 8. Effect of soil solarization and chemical fumigants on soilborne pests and marketable yield of tomato at the validation site III

\begin{tabular}{|c|c|c|c|c|c|c|}
\hline Plastic $^{\mathrm{s}}$ & Soil treatment & Rate $^{t}$ & Paratrichodorus minor $^{\mathrm{u}}$ & Meloidogyne species ${ }^{\mathrm{u}}$ & Root gall ratings ${ }^{\mathrm{v}}$ & Marketable yield $^{\mathrm{w}}$ \\
\hline White & $M B C^{x}$ & $45.0 \mathrm{~g}$ & $31.0 \mathrm{a}^{\mathrm{y}}$ & $18.0 \mathrm{a}$ & $0.0 \mathrm{c}$ & $52.0 \mathrm{ab}$ \\
\hline Clear & MBC & $22.4 \mathrm{~g}$ & $17.2 \mathrm{a}$ & $706.5 \mathrm{a}$ & $1.0 \mathrm{~b}$ & $51.6 \mathrm{ab}$ \\
\hline Clear & None & $\ldots$ & $31.8 \mathrm{a}$ & $385.0 \mathrm{a}$ & $1.8 \mathrm{a}$ & $44.4 \mathrm{~b}$ \\
\hline
\end{tabular}

${ }^{s}$ White = white, low density polyethylene and clear = clear, low density polyethylene solarization film.

${ }^{\mathrm{t}}$ Per square meter.

u Density of nematodes per $100 \mathrm{~cm}^{3}$ of soil.

${ }^{v}$ Estimates of the number of galls per root system using a scale of 0 to 5 in which $0=$ no galls and $5=>100$ galls (52).

${ }^{\mathrm{w}}$ Metric tons per hectare.

${ }^{x}$ A 98:2 mixture of methyl bromide + chloropicrin.

${ }^{y}$ Means in each column followed by the same letter do not differ $(P \leq 0.05)$ according to the Waller-Duncan $k$-ratio $t$ test (root gall ratings and marketable yield) or Duncan's multiple range test (Paratrichodorus minor and Meloidogyne spp.).

${ }^{\mathrm{z}}$ A mixture of 1,3-dichloropropene + chloropicrin. 
fective in reducing populations of Paratrichodorus minor, which commonly recolonizes fumigated soil, although trichodorid recolonization tends to occur from residual populations in deeper soil layers (55) rather than from nonfumigated strips.

Soil solarization provided significant reductions in the incidence of Southern blight and Fusarium wilt and was generally as effective as fumigation with methyl bromide + chloropicrin. Reductions in the incidence of diseases caused by $S$. rolfsii have been reported in other studies; although, in some instances, the effect varied from year to year $(22,43,51)$. Reductions in the incidence of Fusarium wilt of tomato, cumin, and cotton by soil solarization also have been reported $(15,32,36,41)$. Soil solarization resulted in significant levels of disease suppression even though it failed to significantly reduce populations of $F$. oxysporum $\mathrm{f}$. sp. lycopersici in a previous study (8). Suppression of Fusarium wilt in the absence of a direct effect on pathogen survival is considered to be related to the involvement of fluorescent pseudomonads and other microorganisms in solarized soils (15).

The inability of soil solarization to control bacterial wilt agrees with earlier studies $(8,9)$. Previous studies have shown a synergistic interaction between fumigation with methyl bromide + chloropicrin and soil solarization on survival of Ralstonia solanacearum and the incidence of bacterial wilt $(8,9)$. This interaction was not observed in this study, perhaps because strip solarization left untreated areas that served as inoculum sources.

The efficacy of some soil disinfestation tactics was enhanced through the combination of soil solarization and improvements in plastic technology. For example, soil solarization and 1,3-dichloropropene + chloropicrin did not significantly reduce the severity of root galling (Table 5) when used alone. When the treatments were applied under a gas-impermeable plastic, the level of root galling was significantly reduced. While not significant at $P<$ 0.05 , a 10 -fold reduction in the density of Meloidogyne spp. was also observed using this combination. Stapleton et al. (50) did not observe additional reductions in the density of $M$. incognita when soil solarization was combined with 1,3-dichloropropene. In this study, significant reductions occurred only when the gas-impermeable film was added. Polyethylene is only marginally effective in preventing chemical fumigants, including methyl bromide and 1,3-dichloropropene, from escaping into the atmosphere (12). Estimates of emissions of methyl bromide between 40 and $99 \%$ have been reported under LDPE plastic $(18,29)$. The gas-impermeable "Bromotec" plastic (Lawson Mardon Packaging) consists of two layers of LDPE sandwiched around a nylon core. The nylon core gives the film its impermeable properties and has been shown to reduce methyl bromide emissions to levels less than $3 \%$ (7).

Soil amended with cabbage residue prior to solarization did not produce any additional benefits in the suppression of soilborne pests. Other studies have observed beneficial effects from combining cabbage residue with soil solarization treatments $(16,34)$. It is possible that the concentration of antifungal volatile compounds evolved from solarized soil amended with cabbage residue was not high enough to provide additional control under the field conditions in this study. Retention of volatiles through the use of a gas-impermeable film did not improve efficacy. In this study, the cabbage residue was scattered onto the plots and then mixed with the soil as the raised beds were prepared. It was not ground into powder and uniformly mixed as was the case in the study by Gamliel and Stapleton (16). Large pieces of undecomposed cabbage may not have been affected by the heat treatment, and, rather than emitting biotoxic volatiles, may have served as a substrate for $S$. rolfsii, leading to higher levels of Southern blight in the cabbage-amended plots.

Other studies have investigated soil solarization performed on raised beds $(24,25,33,34,44,47)$. This is the first study in which solarization of raised beds was shown to eliminate the border effect that results from a decrease in soil temperatures at the edge of the solarized area (23). With a raised bed, the plastic film on the sides of the bed provides additional surface area for solar radiation to penetrate the soil and functions as a barrier to prevent heat escaping from the edges of the treated area.

The soil solarization treatments were fully compatible with the regional fresh market fall tomato production system. The plastic was applied during the routine application window, and growers did not have to modify their application procedures. The cost of the clear LDPE was half of the cost of white on black, coextruded LDPE. The only additional procedure required of the solarization process was painting the plastic white at the end of the solarization period. The cost of paint was $\$ 135$ per hectare. Per hectare costs of the standard soil disinfestation procedure, including plastic film and methyl bromide + chloropicrin, is approximately $\$ 1,535$. The per hectare cost of the soil solarization treatment, including the paint, is approximately $\$ 548$. Thus, soil solarization was more cost effective, resulting in savings approaching $\$ 1,000$ per hectare. The solarization film provided an added benefit as it was also used as a production mulch after the solarization treatment was completed. Full integration of soil solarization into standard, raised-bed, plastic mulch production systems has been attempted in only a few instances $(24,25,44)$.

Without any soil disinfestation treatment, marketable yields averaged 20.4 metric tons per hectare, which was a $50 \%$ reduction from the Florida state-wide average of 40.1 metric tons per hectare observed between 1991 and 1995 (3). Although less than the $61.4 \%$ reduction in production reported by Spreen et al. (46), this study further substantiates the claim that failure to obtain alternatives to methyl bromide for management of soilborne pests will result in major economic hardships for Florida vegetable producers. For example, using a 5-year average market price of $\$ 7.95$ per $11.35-\mathrm{kg}$ box, the $50 \%$ reduction in marketable yield represents an annual loss of \$281 million from fresh market tomato production in Florida.

In this study, soil solarization was shown to be ideally suited to function as a framework in which to establish an IPM program for soilborne pests. Soil solarization integrated well into the raisedbed, plastic mulch production system, was cost effective, provided significant management of many of the key pests, enhanced the efficacy of other pest management tactics, and permitted reduced dosages of chemical fumigants. The decline in the availability of chemical fumigants coupled with an increase in the availability of biological control agents and new developments in plastic technology will continue to support the utilization of soil solarization in an IPM program for soilborne pests.

\section{ACKNOWLEDGMENTS}

This research was supported, in part, by the Gadsden County Tomato Growers Association and the United States Department of Agriculture, Specific Cooperative Agreement 58-6617-4-019. Florida Agricultural Experiment Station Journal Series R-05256. We thank Y. Katan for critical review of this manuscript and N. T. Garguilo, M. Fletcher, W. Maxwell, and S. Suber for use of their tomato production fields.

\section{LITERATURE CITED}

1. Abdel-Rahim, M. F., Satour, M. M., Mickail, K. Y., El-Eraki, S. A., Grinstein, A., Chen, Y., and Katan, J. 1988. Effectiveness of soil solarization in furrow-irrigated Egyptian soils. Plant Dis. 72:143-146.

2. Anonymous. 1993. The Biological and Economic Assessment of Methyl Bromide. The National Agricultural Pesticide Impact Assessment Program (NAPIAP), USDA, Washington, DC.

3. Anonymous. 1996. Florida Agricultural Statistics, Vegetable Summary. Florida Department of Agriculture \& Consumer Services, Orlando, FL.

4. Bewick, T. A. 1989. Use of soil sterilants in Florida vegetable production. Acta Hortic. 255:61-72.

5. Cantliffe, D. J., Hochmuth, G. J., Locascio, S. J., Stansly, P. A., Vavrina, C. S., Polston, J. E., Schuster, D. J., Seal, D. R., Chellemi, D. O., and Olson, S. M. 1995. Production of solanaceae for fresh market under field conditions: Current problems and potential solutions. Acta Hortic. 
412:229-244

6. Cartia, G., Greco, N., and Cipriano, T. 1989. Effect of solarization and fumigants on soilborne pathogens of pepper in greenhouse. Acta Hortic. 255:111.

7. Chakrabarti, B., Wontner-Smith, T., and Bell, C. H. 1995. Reducing methyl bromide emissions from soil fumigation in greenhouses. Pages 25-1 to 25-3 in: Annual International Research Conference on Methyl Bromide Alternatives and Emissions Reductions. Methyl Bromide Alternatives Outreach, Fresno, CA.

8. Chellemi, D. O., Olson, S. M., and Mitchell, D. J. 1994. Effects of soil solarization and fumigation on survival of soilborne pathogens of tomato in northern Florida. Plant Dis. 78:1167-1172.

9. Chellemi, D. O., Olson, S. M., Scott, J. W., Mitchell, D. J., and McSorley, R. 1993. Reduction of phytoparasitic nematodes on tomato by soil solarization and genotype. J. Nematol. 25(suppl.):800-805.

10. Clean Air Act. 1990. Title VI-Stratospheric Ozone Protection. Pub. L. 101-549, Sect. 6001-618, 104 Stat. 2649, 6272. As amended. U.S. Congress, Washington, DC.

11. Crop Protection Coalition. 1995. Status of methyl bromide alternatives research activities. Crop Protection Coalition, Fresno, CA.

12. Daponte, T. L. F. 1995. Barrier films: Hytibar. Acta Hortic. 382:56-66

13. Federal Register. 1993. Fed. Registr. 58:65018-65082.

14. Frank, Z. R., Ben-Yephet, Y., and Katan, J. 1986. Synergistic effect of metham and solarization in controlling delimited shell spots of peanut pods. Crop Prot. 5:199-202.

15. Gamliel, A., and Katan, J. 1993. Suppression of major and minor pathogens by fluorescent pseudomonads in solarized and nonsolarized soil. Phytopathology 83:68-75.

16. Gamliel, A., and Stapleton, J. J. 1993. Characterization of antifungal volatile compounds evolved from solarized soil amended with cabbage residues. Phytopathology 83:899-905.

17. Gamliel, A., and Stapleton, J. J. 1993. Effect of chicken compost or ammonium phosphate and solarization on pathogen control, rhizosphere microorganisms, and lettuce growth. Plant Dis. 77:886-891.

18. Gan, J., Yates, S. R., Wang, D., and Ernst, F. F. 1995. Reducing fumigant volatilization through optimized application and soil management. Pages 26-1 to 26-2 in: Annual International Research Conference on Methyl Bromide Alternatives and Emissions Reductions. Methyl Bromide Alternatives Outreach, Fresno, CA.

19. Garibaldi, A., and Gullino, M. L. 1991. Use of solarization in marginally suitable climates. Pages 253-265 in: Soil Solarization. J. E. DeVay, J. J. Stapleton, and C. L. Elmore, eds. FAO Plant Prot. Prod. Pap. 109.

20. Ghini, R., Bettiol, W., Spadotto, C. A., de Moraes, G. J., Paraiba, L. C., and Mineiro, J. L. 1993. Soil solarization for the control of tomato and eggplant Verticillium wilt and its effect on weed and micro-arthropod communities. Summa Phytopathol. 19:183-189.

21. Gilreath, J. P., Jones, J. P., and Noling, J. W. 1995. Fumigant/herbicide combinations for polyethylene mulched tomato. Pages $38-1$ to $38-2$ in: Annual International Research Conference on Methyl Bromide Alternatives and Emissions Reductions. Methyl Bromide Alternatives Outreach, Fresno, CA.

22. Grinstein, A., Katan, J., Abdul Razik, A., Zeydan, O., and Elad, Y. 1979. Control of Sclerotium rolfsii and weeds in peanuts by solar heating of the soil. Plant Dis. Rep. 63:1056-1059.

23. Grinstein, A., Kritzman, G., Hetzroni, A., Gamliel, A., Mor, M., and Katan, J. 1995. The border effect of soil solarization. Crop Prot. 14:315320.

24. Hartz, T. K., Bogle, C. R., and Villalon, B. 1984. Response of bell pepper (Capsicum annum) to soil solarization. (Abstr.) HortScience 19:209.

25. Hartz, T. K., DeVay, J. E., and Elmore, C. L. 1993. Solarization is an effective disinfestation technique for strawberry production. HortScience 28:104-106.

26. Heald, C. M., and Robinson, A. F. 1987. Effects of soil solarization on Rotylenchulus reniformis in the Lower Rio Grande Valley of Texas. J. Nematol. 19:93-103.

27. Jacobsen, B. J., and Backman, P. A. 1993. Biological and cultural plant disease controls: Alternatives and supplements to chemicals in IPM systems. Plant Dis. 77:311-315.

28. Jenkins, W. R. 1964. A rapid centrifugal-flotation technique for separating nematodes from soil. Plant Dis. Rep. 48:692.

29. Jin, Y., and Jury, W. A. 1995. Methyl bromide diffusion and emission through soil columns under various management techniques. J. Environ. Qual. 24:1002-1009.

30. Kassaby, F. Y. 1985. Solar-heating soil for control of damping-off diseases. Soil Biol. Biochem. 17:429-434.

31. Katan, J. 1993. Replacing pesticides with nonchemical tools for the control of soilborne pathogens-A realistic goal. Phytoparasitica 21:95-99.
32. Katan, J., Fishler, G., and Grinstein, A. 1983. Short- and long-term effects of soil solarization and crop sequence on Fusarium wilt and yield of cotton in Israel. Phytopathology 73:1215-1219.

33. Keinath, A. P. 1995. Reductions in inoculum density of Rhizoctonia solani and control of belly rot on pickling cucumber with solarization. Plant Dis. 79:1213-1219.

34. Keinath, A. P. 1996. Soil amendment with cabbage residue and crop rotation to reduce gummy stem blight and increase growth and yield of watermelon. Plant Dis. 80:564-570.

35. Locascio, S. J., Dickson, D. W., and Kucharek, T. A. 1995. Fumigant alternative to methyl bromide for polyethylene mulched tomato. Pages 38-1 to 38-2 in: Annual International Research Conference on Methyl Bromide Alternatives and Emissions Reductions. Methyl Bromide Alternatives Outreach, Fresno, CA.

36. Lodha, S. 1995. Soil solarization, summer irrigation and amendments for the control of Fusarium oxysporum f. sp. cumini and Macrophomina phaseolina in arid soils. Crop Prot. 14:215-219.

37. McSorley, R., and Parrado, J. L. 1986. Application of soil solarization to rockdale soils in a subtropical environment. Nematropica 16:125-140.

38. Ohr, H. D., Sims, J. J., Grech, N. M., Becker, J. O., and McGiffen, M. E., Jr. 1996. Methyl iodide, an ozone-safe alternative to methyl bromide as a soil fumigant. Plant Dis. 80:731-735.

39. Overman, A. J. 1985. Off-season land management, soil solarization and fumigation for tomato. Proc. Soil Crop Sci. Soc. Fla. 44:35-39.

40. Porter, I. J., and Merriman, P. R. 1983. Effects of solarization of soil on nematode and fungal pathogens at two sites in Victoria. Soil Biol. Biochem. 15:39-44

41. Ramirez-Villapudua, J., and Munnecke, D. E. 1987. Control of cabbage yellows (Fusarium oxysporum f. sp. conglutinans) by solar heating of field soils amended with dry cabbage residues. Plant Dis. 71:217-221.

42. Ramirez-Villapudua, J., and Munnecke, D. E. 1988. Effect of solar heating and soil amendments of cruciferous residues on Fusarium oxysporum f. sp. conglutinans and other organisms. Phytopathology 78:289295.

43. Ristaino, J. B., Perry, K. B., and Lumsden, R. D. 1991. Effect of solarization and Gliocladium virens on sclerotia of Sclerotium rolfsii, soil microbiota, and the incidence of Southern blight of tomato. Phytopathology $81: 1117-1124$

44. Ristaino, J. B., Perry, K. B., and Lumsden, R. D. Soil solarization and Gliocladium virens reduce the incidence of Southern blight (Sclerotium rolfsii) in bell pepper in the field. Biocontrol Sci. Technol. In press.

45. Smith, S. A., and Taylor, T. G. 1994. Production cost for selected vegetables in Florida. Univ. Fla. Coop. Ext. Serv. Circ. 1146.

46. Spreen, T. H., VanSickle, J. J., Moseley, A. E., Deepak, M. S., and Mathers, L. 1995. Use of methyl bromide and the economic impact of its proposed ban on the Florida fresh fruit and vegetable industry. Univ. Fla. Inst. Food Agric. Sci. Bull. 898

47. Standifer, L. C., Wilson, P. W., and Porch-Sorbet, R. 1984. Effects of solarization on soil weed seed populations. Weed Sci. 32:569-573.

48. Stapleton, J. J., and DeVay, J. E. 1983. Response of phytoparasitic and free-living nematodes to soil solarization and 1,3-dichloropropene in California. Phytopathology 73:1429-1436.

49. Stapleton, J. J., and DeVay, J. E. 1995. Soil solarization: A natural mechanism of integrated pest management. Pages 309-322 in: Innovative Approaches to Integrated Pest Management. R. Reuveni, ed. CRC Press, Boca Raton, FL.

50. Stapleton, J. J., Lear, B. L., and DeVay, J. E. 1987. Effect of combining soil solarization with certain nematicides on target and nontarget organisms and plant growth. Ann. Appl. Nematol. 1:107-112.

51. Stevens, C., Khan, V. A., Collins, D., Rodriguez-Kabana, R., Ploper, L. D., Adeyeye, O., Brown, J., and Backman, P. 1992. Use of soil solarization to reduce the severity of early blight, Southern blight and root-knot in tomatoes. (Abstr.) Phytopathology 82:500.

52. Taylor, A. L., and Sasser, J. N. 1978. Biology, identification and control of root-knot nematodes (Meloidogyne species). North Carolina State University, Raleigh.

53. Tjamos, E. C., and Fravel, D. R. 1995. Detrimental effects of sublethal heating and Talaromyces flavus on microsclerotia of Verticillium dahliae. Phytopathology 85:388-392.

54. Volin, R. B., and McMillan, R. T., Jr. 1973. Response of the tomato cultivar 'Walter' grown on mulch to soil fumigants. Proc. Fla. State Hortic. Soc. 86:159-163.

55. Weingartner, D. P., Shumaker, J. R., and Smart, G. C., Jr. 1983. Why soil fumigation fails to control potato corky ringspot disease in Florida. Plant Dis. 67:130-134.

56. Williamson, C. E., Tammen, J., Hannon, C. I., and Denmark, J. C. 1955. Some tests with soil fumigants. Proc. Fla. State Hortic. Soc. 68:370-373. 